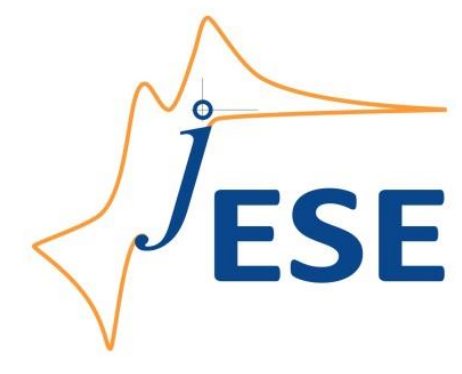

Open Access : : ISSN 1847-9286

www.jESE-online.org

Original scientific paper

\title{
Electrochemical corrosion behavior of Ni-containing hypoeutectic Al-Si alloy
}

\author{
Abul Hossain $\bowtie$, Fahmida Gulshan, Abu Syed Wais Kurny \\ Department of Materials and Metallurgical Engineering, Bangladesh University of Engineering and \\ Technology, Dhaka, Bangladesh
}

${ }^{\square}$ Corresponding Author: ah buetmmesgfl@live.com; Tel: +88-01711243601

Received: March 8, 2015; Revised: May 23, 2015; Accepted: October 17, 2015

\begin{abstract}
Electrochemical corrosion characteristics of the thermally treated 2 wt \% Ni-containing Al-6Si-0.5Mg alloy were studied in $\mathrm{NaCl}$ solutions. The corrosion behavior of thermally treated (T6) Al-6Si-0.5Mg (-2Ni) alloys in $0.1 \mathrm{M} \mathrm{NaCl}$ solution was investigated by electrochemical potentiodynamic polarization technique consisting of linear polarization method using the fit of Tafel plot and electrochemical impedance spectroscopy (EIS) techniques. Generally, linear polarization experiments revealed a decrease of the corrosion rate at thermal treated Al-6Si-0.5Mg-2Ni alloy. The EIS test results showed that there is no significant change in charge transfer resistance $\left(R_{c t}\right)$ after addition of $\mathrm{Ni}$ to Al-6Si-0.5Mg alloy. The magnitude of the positive shift in the open circuit potential $(O C P)$, corrosion potential ( $\left.E_{\text {corr }}\right)$ and pitting corrosion potential $\left(E_{\text {pit }}\right)$ increased with the addition of $\mathrm{Ni}$ to Al-6Si-0.5Mg alloy. The forms of corrosion in the studied Al-6Si-0.5Mg alloy (except Al-6Si-0.5Mg-2Ni alloy) are pitting corrosion as obtained from the scanning electron microscopy (SEM) study.
\end{abstract}

\section{Keywords}

Al-Si alloy; Corrosion; Potentiodynamic; Impedance; SEM

\section{Introduction}

Foundry aluminium alloys based on the Al-Si system are widely used in the automobile field since they provide excellent fluidity and castability, good resistance to corrosion and mechanical properties [1-4]. Corrosion is the dissolution of a metal into an aqueous environment where the metal atoms dissolve as ions. Since corrosion is always a function of the environmental conditions, control in many cases is important in order to prevent the contact between metal and the surrounding environment. The resistance of aluminum against corrosion in aqueous media can be 
attributed to a rapidly formed surface oxide film [5]. Therefore, aluminum has been known to exhibit widely different electrochemical properties in different aqueous electrolytes [6].

Aluminium and its alloys are considered to be highly corrosion resistant under the majority of service conditions [7]. The various grades of pure aluminum are the most resistant, followed closely by the Al-Mg and Al-Mn alloys. Next in order are Al-Mg-Si and Al-Si alloys. The alloys containing copper are the least resistant to corrosion [8] but this can be improved by coating each side of the copper containing alloy with a thin layer of high purity aluminium, thus gaining a three ply metal (Alclad). This cladding acts as a mechanical shield and offers sacrificial protection[9]. When aluminum surfaces are exposed to atmosphere, a thin invisible oxide $\left(\mathrm{Al}_{2} \mathrm{O}_{3}\right)$ layer forms, which protects the metal from further corrosion in many environments [7]. This film protects the metal from further oxidation unless this coating is destroyed, and the material remains fully protected against corrosion [9]. The composition of an alloy and its thermal treatment are important do determine the susceptibility of the alloy to corrosion [10-11].

In Ni-containing alloys the eutectic phase E consists of more or less soft 'eutectic $\mathrm{Al}(\alpha \mathrm{E})$ ' and hard 'eutectic $\mathrm{Si}$ and $\mathrm{Al}_{3} \mathrm{Ni}$ [12]. When $\mathrm{Ni}$ is added to the Al-Si system, the eutectic transformation is characterized by a simultaneous formation of eutectic $\mathrm{Si}$ and $\mathrm{Al}_{3} \mathrm{Ni}$ and consequently, eutectic $\mathrm{Si}$ and $\mathrm{Al}_{3} \mathrm{Ni}$ form a geometrically entangled system. During the course of a solution treatment eutectic $\mathrm{Al}_{3} \mathrm{Ni}$ does not significantly change its shape, as can be metallographically observed. Furthermore, in the presence of $\mathrm{Ni}$-aluminides the loss of interconnectivity of eutectic $\mathrm{Si}$ is significantly reduced [13-14].

In solution treated $\mathrm{Al}-\mathrm{Si}-\mathrm{Mg}$ alloys containing up to $2 \% \mathrm{Ni}$ the positive effect of $\mathrm{Ni}$ is much more prominent, especially with respect to the yield strength. While $\mathrm{Ni}$-containing alloys the contiguity

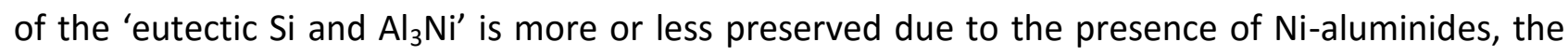
spheroidization of the eutectic $\mathrm{Si}$ in the $\mathrm{Ni}$-free alloy (AISi12Mg) results in its reduced contiguity and thus reduced strength [13-14].

New demanding applications are developed continuously. To be able to make the alloys competitive in future applications, assess to powerful tools and methods for materials or/ properties development is essential. The interest in this work for $2 \mathrm{wt} \% \mathrm{Ni}$ addition to Al-6Si$0.5 \mathrm{Mg}$ alloy comes from the possibility to improve the corrosion resistance in the T6 temper. In this study, electrochemical measurements were recorded to characterize the electrochemical behavior of the Al-6Si-0.5Mg (-2Ni) alloys.

\section{Experimental}

Materials preparation: The Al-6Si-0.5Mg $(-2 \mathrm{Ni})$ alloys were prepared by melting Al-7Si-0.3 Mg (A356) alloys and adding $\mathrm{Al}, \mathrm{Ni}$ and $\mathrm{Mg}$ into the melt. The melting operation was carried out in a gas fired clay graphite crucible furnace and the alloys were cast in a permanent steel mould. After solidification the alloys were homogenised $\left(500{ }^{\circ} \mathrm{C}\right.$ for $\left.24 \mathrm{~h}\right)$, solution treated $\left(540{ }^{\circ} \mathrm{C}\right.$ for $\left.2 \mathrm{~h}\right)$ and finally artificially aged $\left(225^{\circ} \mathrm{C}\right.$ for $\left.1 \mathrm{~h}\right)$. After heat treatment rectangular samples $(30 \times 10 \times 5 \mathrm{~mm})$ were prepared for metallographic observation and subsequent electrochemical test. Deionized water and analytical reagent grade sodium chloride $(\mathrm{NaCl})$ were used for the preparation of $0.1 \mathrm{M}$ solution. All measurements were carried out at room temperature.

Potentiodynamic polarization test: A computer-controlled Gamry Framework TM Series G 300 ${ }^{\text {TM }}$ and Series G $750^{\text {тM }}$ Potentiostat/ Galvanostat/ZRA was used for the electrochemical measurements. The potentiodynamic polarization studies were configured in cells, using three-electrode assembly: a saturated calomel reference electrode, a platinum counter electrode and the sample 
in the form of coupons of exposed area of $0.50 \mathrm{~cm}^{2}$ or $10 \times 5 \mathrm{~mm}$ as working electrode. Only one $10 \times 5 \mathrm{~mm}$ surface was exposed to the test solution, the other surfaces being covered with Teflon tape. The system was allowed (100 s) to establish a steady-state open circuit potential (OCP). The potential range selected was -1 to $+1 \mathrm{~V}$ and measurements were made at a scan rate of $0.50 \mathrm{mV} / \mathrm{s}$. The corrosion current $\left(I_{\text {corr }}\right)$, corrosion potential $\left(E_{\text {corr }}\right)$, pitting corrosion potential $\left(E_{\text {pit }}\right)$ and corrosion rate (mpy) were calculated from Tafel curve. The tests were carried out at room temperature in solutions containing $0.1 \mathrm{M}$ of $\mathrm{NaCl}$ at a fixed and neutral $\mathrm{pH}$ value. The corroded samples were cleaned in distilled water and examined under scanning electron microscope.

Electrochemical impedance spectroscopy (EIS) test: As in potentiodynamic polarization test, three electrode cell arrangements were also used in electrochemical impedance measurements. Rectangular samples $(10 \times 5 \mathrm{~mm})$ were connected with copper wire and adopted as working electrode. EIS tests were performed in $0.1 \mathrm{M} \mathrm{NaCl}$ solution at room temperature over a frequency range of $100 \mathrm{kHz}$ to $0.2 \mathrm{~Hz}$ using a $5 \mathrm{mV}$ amplitude sinusoidal voltage. The $10 \times 5 \mathrm{~mm}$ sample surface was immersed in $0.1 \mathrm{M} \mathrm{NaCl}$ solution (electrolyte). All the measurements were performed at the open circuit potential (OCP). The test cells were maintained at room temperature and the $\mathrm{NaCl}$ solution was refreshed regularly during the whole test period. The impedance spectra were collected, fitting the experimental results to an equivalent circuit (EC) using the Echem Analyst ${ }^{\mathrm{TM}}$ data analysis software and evaluating the solution resistance $\left(R_{s}\right)$, polarization resistance or charge transfer resistance $\left(R_{\mathrm{ct}}\right)$ and double layer capacitance $\left(C_{\mathrm{p}}\right)$ of the thermal treated alloys.

\section{Results and discussion}

Table 1 shows the Electrochemical Impedance Spectroscopy (EIS) test results.

Table 1. Impedance test results

\begin{tabular}{ccccc}
\hline Alloy compositions & \multicolumn{1}{c}{$R_{\mathrm{s}} / \Omega$} & $R_{\mathrm{ct}} / \mathrm{k} \Omega$ & \multicolumn{1}{c}{$C_{\mathrm{p}} / \mu \mathrm{F}$} & OCP, $\mathrm{V}$ vs.SCE \\
\hline Al-6Si-0.5Mg & 40.37 & 15.57 & 1.259 & -0.8454 \\
Al-6Si-0.5Mg-2Ni & 40.53 & 14.44 & 1.645 & -0.6814 \\
\hline
\end{tabular}

Table 2 shows the potentiodynamic polarization test results obtained from the electrochemical tests.

Table 2. Potentiodynamic polarization test results

\begin{tabular}{crccc}
\hline Alloy compositions & $I_{\text {corr }} / \mu \mathrm{A}$ & $E_{\text {corr }} / \mathrm{mV}$ & $E_{\text {pit }} / \mathrm{mV}$ & Corrosion rate, $\mathrm{mm} /$ year \\
\hline Al-6Si-0.5Mg & 6.30 & -764 & -480 & 5.287 \\
Al-6Si-0.5Mg-2Ni & 2.54 & -720 & -426 & 2.132 \\
\hline
\end{tabular}

\section{Electrochemical corrosion characteristics}

\section{Electrochemical Impedance Spectroscopy}

The open circuit potential (OCP) with exposure time of aged Al-6Si-0.5Mg (-2Ni) alloys in $0.1 \mathrm{M} \mathrm{NaCl}$ solution is shown in Table 1. Large fluctuations in open circuit potential for the alloys were seen initially but, after a period of exposure the OCP fluctuation decreased and reached steady state. The steady state OCP of Ni free alloy (Al-6Si-0.5Mg) is $-0.8454 \mathrm{~V}$ and the Al-6Si-0.5Mg$2 \mathrm{Ni}$ alloy $-0.6814 \mathrm{~V}$. The OCP values mainly depend on the chemical compositions and thermal history of the alloys. 
The data obtained were modeled and the equivalent circuit that best fitted to the experimental data is shown in Figure 1. $R_{\mathrm{s}}$ represent the ohmic solution resistance of the electrolyte. $R_{\mathrm{ct}}$ and $C_{\mathrm{p}}$ are the charge transfer resistance and electrical double layer capacitance respectively, which correspond to the Faradaic process at the alloy/media interface. Figure 2 shows the Nyquist diagrams (suggested equivalent circuit model shown in Figure 1) of the Al-6Si-0.5Mg (-2Ni) alloys in $0.1 \mathrm{M} \mathrm{NaCl}$ in de-ionized water. In Nyquist diagrams, the imaginary component of the impedance $\left(Z^{\prime \prime}\right)$ against real part $\left(Z^{\prime}\right)$ is obtained in the form of capacitive-resistive semicircle for each sample.

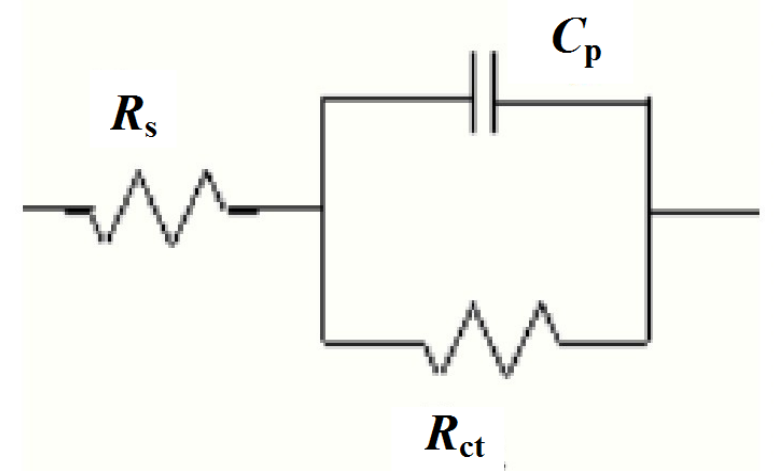

Figure 1. Electrical equivalent circuit used for fitting of the impedance data of Al-6Si $0.5 \mathrm{Mg}(-2 \mathrm{Ni})$ alloys

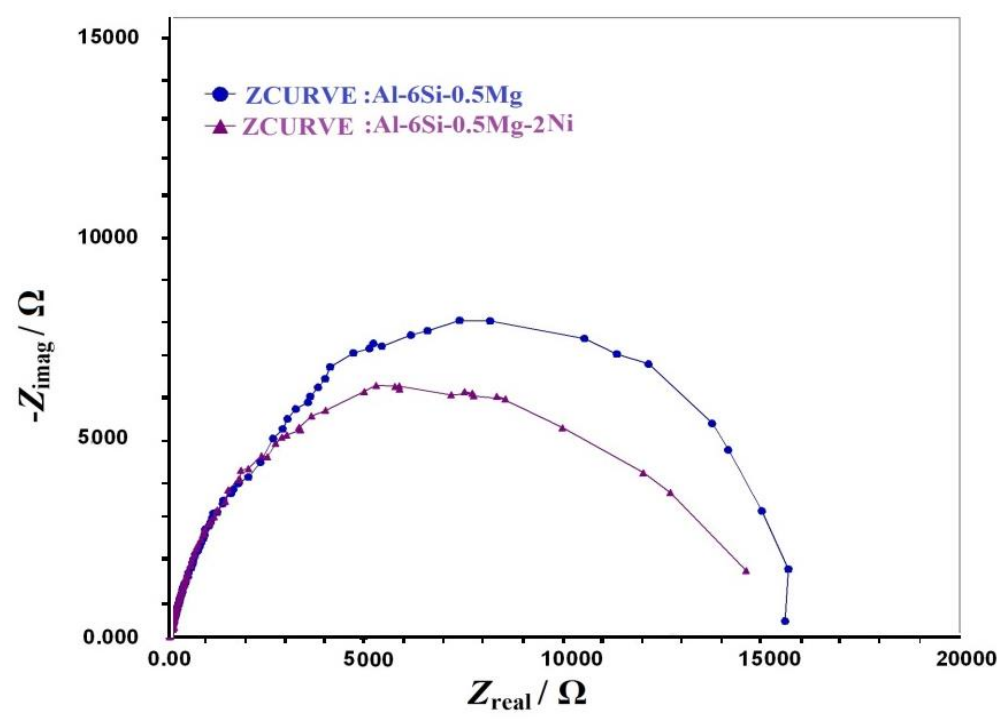

Figure 2. Nyquist plots for the Al-6Si-0.5Mg (-2Ni) alloys

Figure 3 shows the experimental EIS results in Bode magnitude diagram for Al-6Si-0.5Mg (-2Ni) alloys. Bode plots show the total impedance behaviour against applied frequency. At high frequencies, only the very mobile ions in solution are excited so that the solution resistance $\left(R_{\mathrm{s}}\right)$ can be assessed. At lower intermediate frequencies, capacitive charging of the solid-liquid interface occurs. The capacitive value $C_{p}$ can provide very important information about oxide properties when passivation or thicker oxides are formed on the surface. At low frequency, the capacitive charging disappears because the charge transfer of electrochemical reaction can occur and this measured value of the resistance corresponds directly to the corrosion rate. For this reason, this low frequency impedance value is referred to as polarization or charge transfer resistance $\left(R_{\mathrm{ct}}\right)$. 
The solution resistances $\left(R_{\mathrm{s}}\right)$ of the alloys (Table. 1 ) are very similar to each other. So there are insignificant changes of $R_{\mathrm{s}}$ values for the alloys during EIS testing. The $R_{\mathrm{s}}$ values are negligible with respect to $R_{\mathrm{ct}}$ and the electrolyte behaves as a good ionic conductor. Impedance measurements showed that in $0.1 \mathrm{M} \mathrm{NaCl}$ solution, for the $\mathrm{Ni}$ free $\mathrm{Al}-6 \mathrm{Si}-0.5 \mathrm{Mg}$ alloy, the charge transfer resistance $\left(R_{\mathrm{ct}}\right)$ value in $0.1 \mathrm{M} \mathrm{NaCl}$ solution is $15.57 \mathrm{k} \Omega$, and this is slightly decreased to $14.44 \mathrm{k} \Omega$ with the addition of $2 \mathrm{wt} \% \mathrm{Ni}$ to the $\mathrm{Al}-6 \mathrm{Si}-0.5 \mathrm{Mg}$ alloy. The decrease in the charge transfer resistance indicates a decrease in the corrosion resistance of the alloy with $\mathrm{Ni}$ addition. The double layer capacitance $\left(C_{\mathrm{p}}\right)$ of the $\mathrm{Ni}$ free $\mathrm{Al}-6 \mathrm{Si}-0.5 \mathrm{Mg}$ alloy is $1.259 \mu \mathrm{F}$, which is the lower value between the alloys investigated. The double layer capacitance $(1.645 \mu \mathrm{F})$ of Al-6Si-0.5Mg alloy increased with an addition of $2 \mathrm{wt} \% \mathrm{Ni}$.

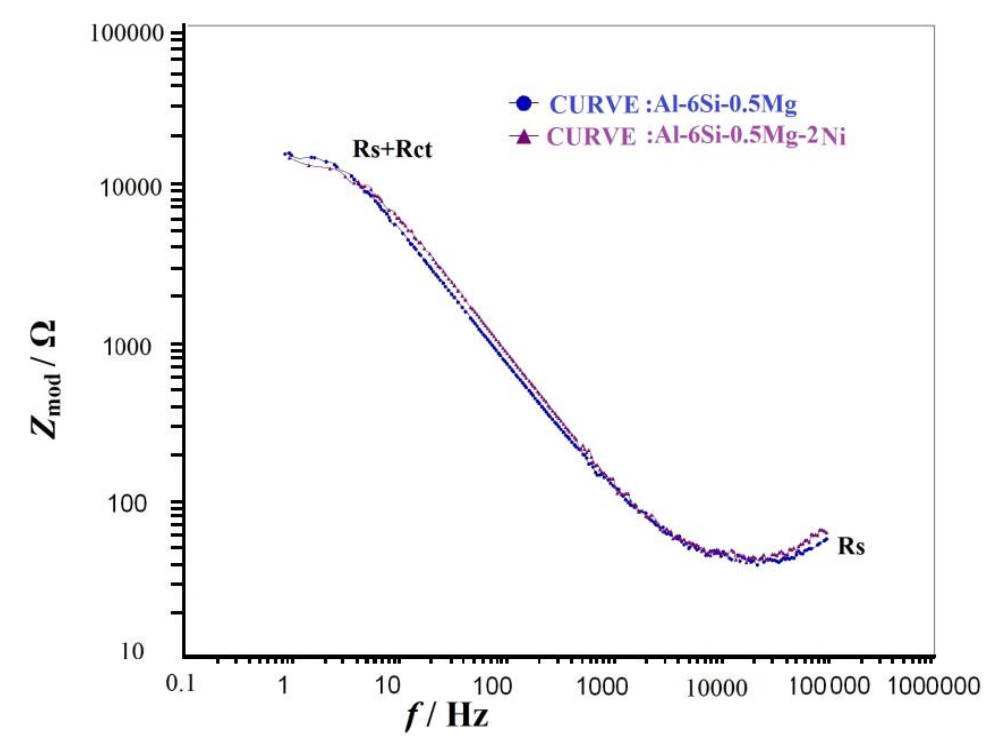

Figure 3. Bode plots for the Al-6Si-0.5Mg (-2Ni) alloys

Potentiodynamic polarization

Potentiodynamic polarization curves of Al-6Si-0.5Mg (-2Ni) alloys are shown in Figure 4. Anodic current density of $\mathrm{Al}-6 \mathrm{Si}-0.5 \mathrm{Mg}$ alloy increased with $\mathrm{Ni}$ addition. The addition of $\mathrm{Ni}$ caused the formation of micro-galvanic cells in $\alpha$-Al matrix.

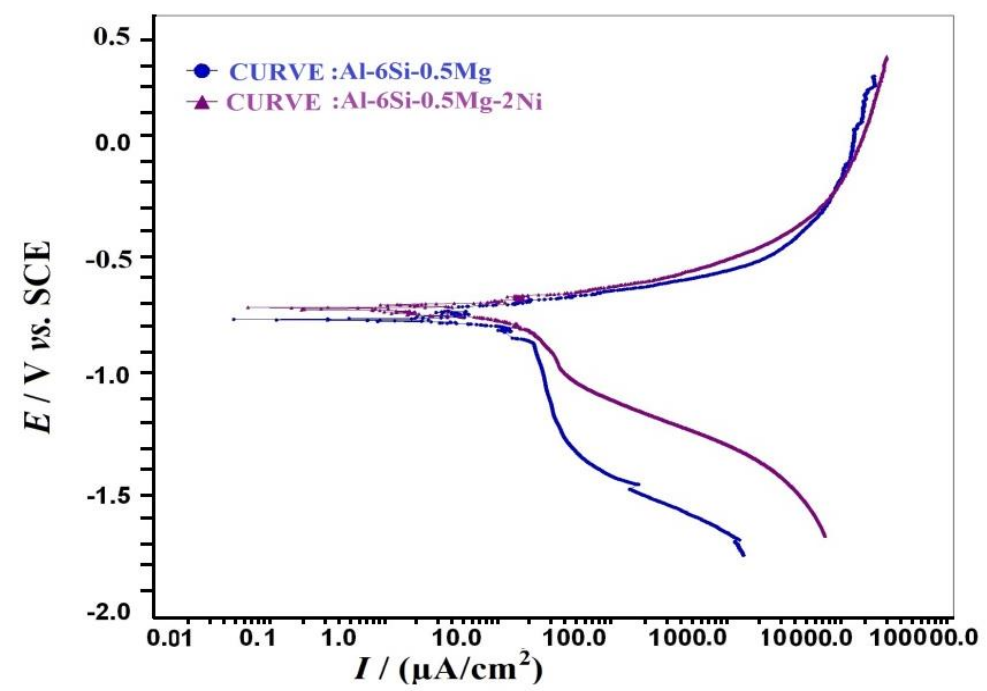

Figure 4. Potentiodynamic polarization curves for the thermal aged Al-6Si-0.5Mg (-2Ni) alloys 
The different intermetallic compounds (like $\mathrm{Mg}_{2} \mathrm{Si}, \mathrm{Al}_{3} \mathrm{Ni}$ etc.) can lead to the formation of micro-galvanic cells because of the difference of corrosion potential between intermetallics and $\alpha$ aluminum matrix. With the addition of $2 \mathrm{wt} \% \mathrm{Ni}$, the corrosion potential of the alloy shifted towards more positive value $(-720 \mathrm{mV})$. Pitting corrosion potential $\left(E_{\text {pit }}\right)$ of the Ni content alloys also shifted towards more positive values (from $-480 \mathrm{mV}$ to $-426 \mathrm{mV}$ ). Potentiodynamic tests showed that in $0.1 \mathrm{M} \mathrm{NaCl}$ solution, addition of $\mathrm{Ni}$ in the Al-6Si-0.5Mg alloy decreases the corrosion current $\left(I_{\text {corr }}\right)$. For the $\mathrm{Ni}$ free Al-6Si-0.5Mg alloy, the corrosion current $\left(I_{\text {corr }}\right)$ value in $0.1 \mathrm{M} \mathrm{NaCl}$ solution is $6.3 \mu \mathrm{A}$, and this decreased to $2.54 \mu \mathrm{A}$ with the addition of $2 \mathrm{wt} \% \mathrm{Ni}$ to the Al-6Si-0.5Mg alloy and the corresponding corrosion rate decreases for the alloy (Al-6Si-0.5Mg-2Ni alloy $=2.132 \mathrm{~mm} /$ year).

\section{Microstructural investigation}

The microstructures of some selected as-corroded samples were observed under SEM. Several pits were visible in the $\mathrm{Ni}$ free sample examined. It is probable that the pits are formed by the intermetallics dropping out from the surface due to the dissolution of the surrounding matrix. However, it is also possible that the pits are caused by selective dissolution of the intermetallic/or particles of the second phase precipitates.

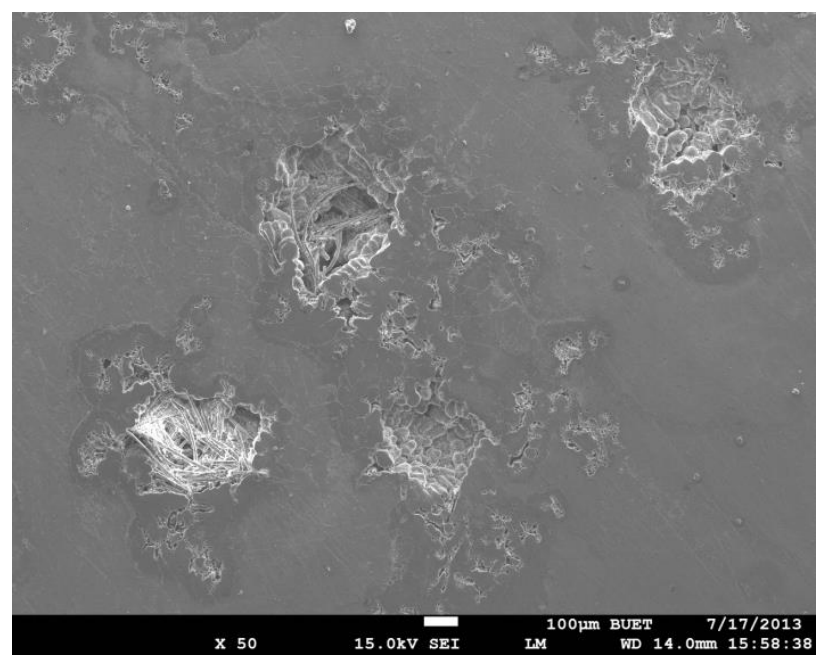

Figure 5. SEM Secondary Electron Image of the damaged surface morphology of as-corroded Al-6Si-0.5Mg alloy.

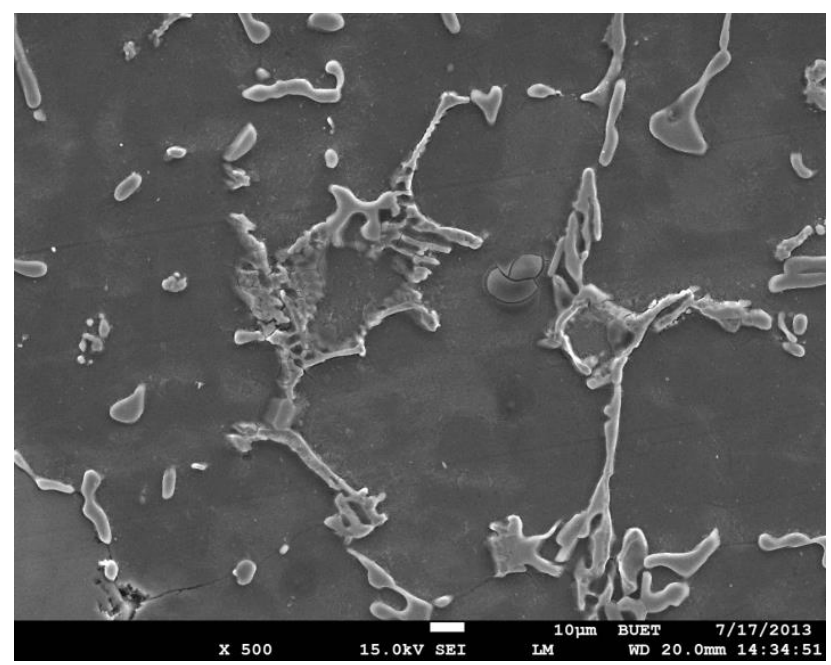

Figure 6. SEM Secondary Electron Image of the damaged surface morphology of Al-6Si-0.5Mg-2Ni alloy. 
No severe pitting corrosion found in the studied Al-6Si-0.5Mg-2Ni alloy, examined by the SEM. All surfaces were characterized by SEM following potentiodynamic polarization tests. The thermal treated $\mathrm{Ni}$ free alloy (Al-6Si-0.5Mg) exhibited pits on their surface (Figure 5), which apparently had nucleated randomly. Conversely, the exposed surface of the alloy exhibited a corrosion product with covering the surface after polarization. All the micrographs (Figures 5-6) also showed that there was no corrosion in the fragmented and modified Al-Si eutectics and Ni containing eutectics $\left(\mathrm{Al}{ }_{3} \mathrm{Ni}\right)$.

\section{Conclusions}

The EIS tests have shown that the additions of $2 \mathrm{wt} \% \mathrm{Ni}$ into $\mathrm{Al}-6 \mathrm{Si}-0.5 \mathrm{Mg}$ alloy tend to slightly decrease the corrosion resistance of Al-6Si-0.5Mg alloy. The linear polarization and Tafel extrapolation plot showed that the corrosion current $\left(I_{\text {corr }}\right)$ and corrosion rate (mm/year) decreased with the addition of $2 \mathrm{wt} \% \mathrm{Ni}$ into Al-6Si-0.5Mg alloy. The open circuit potential (OCP), corrosion potential $\left(E_{\text {corr }}\right)$ and pitting corrosion potential $\left(E_{\text {pit }}\right)$ were shifted in the more noble direction due to $\mathrm{Ni}$ additions into Al-6Si-0.5Mg alloy. No severe pits found in the studied Al-6Si$0.5 \mathrm{Mg}-2 \mathrm{Ni}$ alloy, examined by the SEM.

\section{References}

[1] P. Leo, E. Cerri, Metallurgical Science and Technology 21 (2003) 27-31.

[2] O. El Sebaie, A. M. Samuel, F. H. Samuel, H. W. Doty, Materials Science and Engineering A 480 (2008) 342-355.

[3] M. Haghshenas, A. Zarei-Hanzaki, S. M. Fatemi-Varzaneh, Materials Science and Engineering A 480 (2008) 68-74.

[4] S. B. Hassan, V. S. Aigbodion, J Alloys and Compds 486 (2009) 309-314.

[5] G. E. Kiourtsidis, S. M. Skolianos, Corrosion Science, 49 (2007) 2711-2725.

[6] Z. Szklarska-Smialowska, Corrosion Science 41(1999) 1743-1767.

[7] M. G. Fontana, N.D. Greene, Corrosion Engineering, McGraw-Hill book Company, New York, 1987, 8-29.

[8] S. Zor, M.Zeren, H.Ozkazance, E. Karakulak, Anti-Corrosion Methods and Materials 57 (2010) 185-191.

[9] G. M. Scamans, J. A. Hunter, N. J. H. Holroyd, , Proc. of 8th Inter. Light Metals Congress, Leoban Wien, 1989, 699-705,

[10] M. Czechowski, Advanced Materials science 7 (2007) 13-20.

[11] M. Abdulwahab, I. A. Madugu, S. A. Yaro, A. P. I. Popoola, Journal of Minerals \& Materials Characterization \& Engineering 10 (2011) 535-551.

[12] Z. Asghar, G. Requena, F. Kubel, Materials Science and Engineering A 527(2010) 5691-5698.

[13] F. Stadlerl, H. Antrekowitsch, W. Fragner, H. Kaufmann, P. J. Uggowitzer, Materials Science Forum 690 (2011) 274-277.

[14] F. Stadlerl, H. Antrekowitsch, W. Fragner, H. Kaufmann, P. J. Uggowitzer, International Journal of Cast Metals Research 25(4) (2012) 215-224. 